\title{
Influence of Organizational Leadership on Knowledge Transfer in Construction
}

\author{
Katun M. İdris ${ }^{1}$, Kherun N. Ali ${ }^{1} \&$ Aliagha U. Godwin ${ }^{2}$ \\ ${ }^{1}$ Faculty of Built Environment, Universiti Teknologi Malaysia, Johor, Malaysia \\ ${ }^{2}$ Faculty of Geoinformation \& Real Estate, Universiti Teknologi Malaysia, Johor, Malaysia \\ Correspondence: Katun M. Idris, Faculty of Built Environment, Universiti Teknologi Malaysia, Johor, Malaysia. \\ E-mail: idriskt@gmail.com
}

Received: March 29, 2015 Accepted: April 24, 2015 Online Published: July 6, 2015

doi:10.5539/ass.v11n21p102 URL: http://dx.doi.org/10.5539/ass.v11n21p102

\begin{abstract}
Organizations are becoming more cognizant that transferring the supremacy of knowledge in business is precarious to attaining reasonable modifications. This research investigates the significant role of organizational leadership on knowledge transfer in the multinational construction organization in Nigeria. Thus, this research was based on the multinational construction organization as a result of their technological advancement on knowledge management, knowledge transfer and development process. The research study adopted empirically validated measures' variables and established a hypothetical framework that links organizational leadership with knowledge transfer variables. 220 survey questionnaires were distributed to knowledge workers of 35 multinational construction organization, and the research validated the framework with structural equation modeling (SEM). The factor's loadings for the variables measures were significant and Cronbash Alpha factors of 0.903 and 0.747 for organizational leadership and knowledge transfer respectively was achieved. The research finding display that organizational leadership demonstrated significant influence on knowledge transfer.
\end{abstract}

Keywords: knowledge transfer, construction, organization, leadership and theoretical framework

\section{Introduction}

In global economy, knowledge is predictable as an essential benefit to the construction organization. Transfer of knowledge has become one process to the knowledge management (Albino et al., 2004). Numerous researchers have to argue that for organizational goal to be achieved, organizational leadership must involve a knowledge management process (Cohen \& Olsen, 2015; Nonaka, 2005; O'Dell \& Grayson Jr., 1998). Organizational leadership can comprise different interpretations, especially ability to inspire confidence, support transfer of knowledge and motivate the staffs to achieve organization goals. Mostly, project leaderships within organizations are created to encourage innovation and engender more ideas, skills. It is affirmed that organizational teams work are more creative than personal or distinctive works (Grint, 2007). Organization leadership should identify an individual strengths, encourage teamwork and provide a better enabling environment that brings distinctive differences to work together. Mostly, successful organizations depend highly on competencies of their leadership and general management skill of their knowledge. Sometime organization leadership and organization management are used interchangeably (Toor \& Ofori, 2008). Thus, the approaches are different; organizational managements are referred to as a progression that employs a scheme of tools with consecutive measures to track how project knowledge are manage efficiently. Organization leadership, on the other hand, is more treasured as it focused on the personal involvement of, knowledge workers from the organization with their intangible values, ideas, skill and experiences aimed for organization success (Hoch and Kozlowski, 2014). Organizational leadership, needs to be multidisciplinary in their attitudes, activities, method of transferring and managing knowledge in their respective domain. Organizational leadership, should engender required hallucination, persuasively build up trust for the workers and have high respect for workers to encourage transfer of knowledge and provide sustenance and direction for it staffs.

Knowledge transfer can be referred to as procedure in which some units of organization are transformed by the skill of other units or people (Nousala et al., 2007). Transfer of knowledge hinges on personal views and individualities such as know-how, ethics, inspiration, theories and experience. O'Dell and Grayson Jr. (1998) on 
the other hand, argues that knowledge transfer is the ability of groups or workers with an organization to integrate and smear current knowledge by linking it to be passed existed knowledge. Thus, transfer of knowledge is always pretentious by the association between the springs and beneficiary. Knowledge transfer is said to occur when experiences and skills existing in individuals or groups affect the way experiences of individual and skill are erudite and achieved (Pollack, 2012). Knowledge transfer at the organizational level is a system where organizations prefabricates and upholds a multifarious practice in a novel surroundings (Von Krogh et al., 2012). Transfer of knowledge is said to be positive if attainment or recitals of the latest information, skill and experience are facilitated, while transfer is negative if attainment or recital of information is impeded. Davenport et al. (1997) argue that transfer is said to occur when both the communication of knowledge to a receiver and fascination is said to have taken place either at individual level or group level. Nonaka (2005) classified knowledge as tacit and explicit. Tacit is that ideas, skills and experiences that can be arrayed and unglued effortlessly from individual minds while explicit is that ideas, skill and experience that can be detached from decision making activities (books, journals, seminars, etc.). Organization leadership can encumber creativity and modernization between groups or distinctive without enormous latent of knowledge and communication technologies. Organization knowledge can be apprehended, arranged and deposited in repositories, which can be easily transfer, retrieved by other organization coworkers (Voon, 2007). Thus, for effective transfer of knowledge from repositories, contribution of knowledge is inevitable and adoption is necessary for reused. Therefore, knowledge transfer through social solidity and technology is proficient in creating good ideas and information. Knowledge transfer is easily obtainable when emotional intelligent of the leader, leadership traits and team transformation with cohesion is strengthened.

\subsection{Knowledge Transfer}

Some researchers have accentuated on the domineering of knowledge transfer and modernization in organization development. Knowledge transfer is an imperative proclaim for construction business to accomplish maintainable and global completive improvement (Widén-Wulff \& Ginman, 2004). In the construction organization transfer of knowledge can be regarded as human common promise and connections that involve an interchange of skill, information, ideas and experiences for operational development of the organization (Von Krogh et al., 2012). Knowledge transfer in an organization is a method where the know-how and skill of the individual or group has being reused and new knowledge form to the organization with the intention of creating innovative policy and solving problems. Knowledge transfer is said to occur in organization when people or employers choose to transfer it store talents, skills and experience with others within the organization (Turner \& Makhija, 2006). Szulanski (2000) considered organizational members, organization mission and their technical tools for possible collaborations and how it affects the efficiency, of knowledge transfer and creation. The author argues that transfer between beneficiary and source is facilitated by technological tools within organization. Transfer of knowledge can be viewed as an object or as a process. Transfer as an object can be perceived, deposited, recycled while transfer as a process is a movement of cooperating changes in individuals who absorb (Singh et al., 2006). Thus, in achieving a necessary knowledge transfer among individuals or group within organization, knowledge transfer institution ought to be in ground to serve as helpful possessions that encourage organizational leadership to motivate workers in transferring knowledge among his workers. Transfer of knowledge comprises of altercation of both employees and employers' tangible, codified, unmodified knowledge for the organizational benefit (Rowley, 2008). Transfer can happens either at individual levels or at group level for the up liftmen of organization to avoid repetitive occurrences of mistakes. At organizational level transfer of knowledge involves establishing, transmission and reprocessing skills, experience based knowledge (Pemsel \& Müller, 2012). Ajzen (1991) and Barnes (2001) argues in their philosophies that knowledge transfer can be anticipated by humane approach and their eccentric customs where humane approach toward transfer is described as incorporates transfer of knowledge and experiences arising from groups, people within the organization that have the desire to transfer; eccentric custom to transfer represents organizational group and staff ready to transfer their ideas; readiness to transfer is described as humane confidence to be involve in transfer. Thus, the potentiality of organizational leadership to provide an enabling environment for societal happening and interactions as a societal solidity in their respective organization put it to somebody a supposition that organization leadership is capable of prompting the transfer of knowledge.

\section{Research Methodology}

Transfer of knowledge was accessed using three constructs: transferring using social networking, approaches towards transferring and readiness to transfer, which was adopted and modified from Szulanski (2000), Xu and $\mathrm{Ma}$ (2008) and Parent et al. (2007) as shown in Table 1. Three indicators were used to measure transferring using the social network (codification, knowledge repositories and database). Approach to transferring knowledge was 
measured with three indicators comprising an exchange through personal contacts, exchange of pertinent information and exchange of pertinent ideas and skills arising from a person. Readiness to transfer by construction workers and other staffs was assessed through intention to transfer and workers' confidence, which is betrothed in knowledge transfer conduct (Szulanski, 2000).

Organizational leadership was measured using three latent constructs namely: emotional intelligent, leadership traits and project team transformation as suggested by Gallos (2014) and Goleman et al. (2013). The indicators that measure impassioned bright, includes self-awareness and self-control, motivation, charisma as suggested by (Akhavan Tabassi et al., 2014; Grint, 2007). Leadership traits were measure with five indicators such as good listener and open mind, leadership vision, delegation to task work, inspiring team work and flexibility of the leaders as suggested by Lopez (2014) and Müller and Turner (2007). Thus, team transformation was measured using four indicators; increasing people's awareness on the benefit of knowledge transfer, helping team group to self -fulfillment, commitment to greatness and trust building as suggested by Müller and Turner (2007), Senaratne et al. (2015) and Turner and Müller (2006). Table 1 presents the adopted measuring variables as they are validated.

Table 1. Summary of measuring indicators adopted for the study

\begin{tabular}{|c|c|c|c|}
\hline Measuring indicators & References & Validity & Recommended \\
\hline \multicolumn{4}{|l|}{ Organizational leadership } \\
\hline 1 Emotional intelligent & $\begin{array}{l}\text { Muller \& Turner, 2007; Lopez, 2014; } \\
\text { Turner \& Muller, } 2005\end{array}$ & Validated empirically & Recommended \\
\hline 2 leadership traits & $\begin{array}{c}\text { Gallos, 2014; Muller \& Turner, 2007; } \\
\text { Grint, } 2007\end{array}$ & Validated empirically & Recommended \\
\hline 3 transformation team & $\begin{array}{l}\text { Muller \& Turner, 2007; Senaratne, 2015; } \\
\text { Goleman, } 2013\end{array}$ & Validated empirically & Recommended \\
\hline \multicolumn{4}{|l|}{ Knowledge transfer } \\
\hline 1 Approach toward transfer & $\begin{array}{c}\text { Szulanski, 2000; Xu \& Ma, 2008; Parent et } \\
\text { al., } 2007\end{array}$ & $\begin{array}{l}\text { Validated empirically } \\
\text { (SEM) }\end{array}$ & Recommended \\
\hline 2 Using social network & $\begin{array}{c}\text { Szulanski, 2000; Xu \& Ma, 2008; Parent et } \\
\text { al., } 2007\end{array}$ & $\begin{array}{l}\text { Validated empirically } \\
\qquad(\mathrm{SEM})\end{array}$ & Recommended \\
\hline 3 Readiness to transfer & $\begin{array}{c}\text { Szulanski, 2000; Xu \& Ma, 2008; Parent et } \\
\text { al., } 2007\end{array}$ & $\begin{array}{l}\text { Validated empirically } \\
\qquad(\mathrm{SEM})\end{array}$ & Recommended \\
\hline
\end{tabular}

\subsection{Hypothesis Development}

In the construction organization, knowledge transfer process view knowledge about an entity which can be shared automatically from the originator to the interpreter who accepts and communicates the ideas to end users (Parent et al., 2007). Knowledge is buried in the worker's know-how and heads as it is gaining much more momentum in research areas of different discipline (Pollack, 2012). Nonaka et al. (2005) argue that knowledge can either be unexpressed or explicit. Unexpressed knowledge is obtainable through experiences, skill and philosophy while explicit knowledge is the ideas obtained through, textbooks, journals, seminars, etc. According to the communal constructive theory, knowledge is transferred and communicated in communal situation. Thus, knowledge is an unstable paradigm that changes as it is dismissed, transfer and re-claimed (Leana \& Pil, 2006). Ashforth and Mael (1989) further argue that the relationships between knowledge and human society are globular or rounded rather than undeviating. Hence, knowledge transfer is a merchandise of the operative group of communal solidity and attitudes, different approach to transfer within a communal system in the construction organization and idiosyncratic customs that oversee transferring anticipation (Albino, et al., 2004). The community and construction environment depends on these long-time variables. Human behavior or deed is a social influence to implement or not to implement (Kuo \& Young, 2008; Parent et al., 2007), however, approaches towards knowledge transfer reflect individual readiness to implement an act or conduct. Organizational attitude or approach obviously influences the transfer of knowledge (Yang et al.; Yang \& Farn, 2009). Koballa (1988) and Ajzen (2001) argues in their theories that attitude and idiosyncratic customs are determinant of individual purpose to implement an act. Therefore, the relationship between organization leadership and social solidity indicates that there is an influence of organizational leadership on knowledge 
transfer. The proposed measurement, analysis model was developed as shown in Figure 1 with the following hypotheses;

H1: organization leadership demonstrated statistically influence on knowledge transfer

H1a. EI can influence positively OL

H1b. LT can influence positively OL

H1c. TT can influence positively OL

H1d. TSN can influence positively KT

H1e. ATT can influence positively KT

H1f. RT can influence positively KT

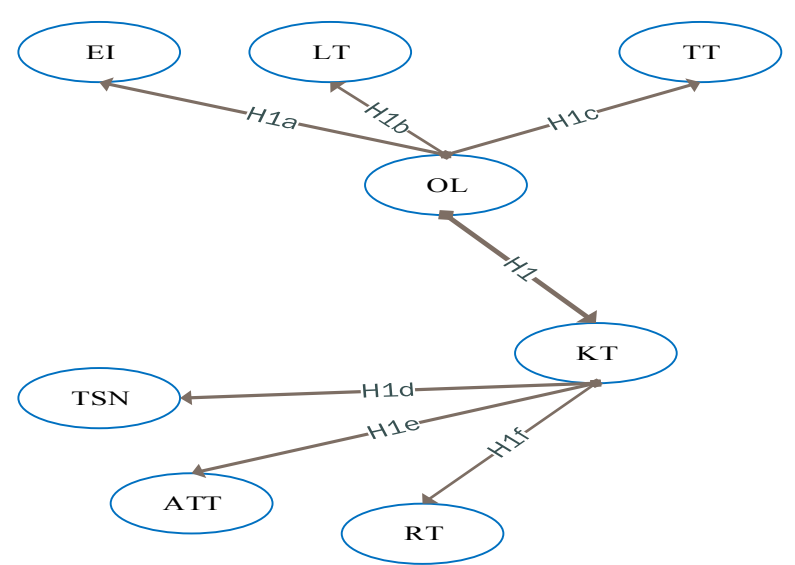

Figure 1. Proposed confirmatory analysis model of organization leadership and knowledge transfer

Note. $\mathrm{KT}=$ Knowledge Transfer, $\mathrm{RT}=$ Readiness to transfer, $\mathrm{TSN}=$ Transfer using Social network, ATT $=$ Attitude towards transfer, $\mathrm{OL}=$ Organization Leadership, $\mathrm{TT}=$ Transformation Team, LT= Leadership Traits, $\mathrm{EL}=$ Emotional Intelligent.

\section{Analysis and Result}

3.1 Result Summary for Exploratory Factor Analysis (EFA)

Table 2. Test of reliability-KMO and Bartlett's Test for organizational leadership

\begin{tabular}{cc}
\hline Analysis & Results \\
\hline Kaiser-Meyer-Olkin Measure of Sampling Adequacy & .878 \\
Bartlett's Test of Sphericity Approx. Chi-Square & 1676.014 \\
$d f$ & 36 \\
Sig. & .000 \\
\hline
\end{tabular}

The Kaiser-Mayer-Okin (KMO) measures of sampling accuracy for the organization's leadership after, measure of sampling activities (MSA), population correlation matrix as well as Bartlett's Test of shericity display as follows; the value of KMO .878 is above recommended values of.5 by (Byrne, 2013) and the p value is significant, the total variance extracted for the exploratory factor analysis (EFA) is $56.633 \%$ and $14.797 \%$. Therefore, the result of factor analysis is meaningful.

Table 3. Test of reliability-KMO and Bartlett's Test for knowledge transfer

\begin{tabular}{cc}
\hline Analysis & Result \\
\hline Kaiser-Meyer-Olkin Measure of Sampling Adequacy. & .731 \\
Bartlett's Test of Sphericity Approx.Chi-Square & 1588.316 \\
$d f$ & 36 \\
Sig. & .000 \\
\hline
\end{tabular}


Original measures of knowledge transfer consist of nineteen indicator. Table 2 indicate the result of EFA with homogeneity of the indicators; the Kaiser-Meyer-Olkin measure sample of adequacy is .731 also exceeding 0.5 as lower boundary if factor analysis was to be evocative (Byrne, 2013; Cohen, 2013). The factor analysis extracted two factors with eigenvalue above one, thus the factor explains $33.566 \%$ and $20.744 \%$ of the variance.

\subsection{Confirmatory Factor Analysis}

The confirmatory factor analysis is used to analyse the model as proposed by (Bollen, 1998). The p-value recorded 0.001 with all the factor loading above the 0.5 benchmark recommended by (Byrne, 2012). The average variance extracted as shown in Table 4 is also above the recommended benchmark of 0.6 as suggested by (Zainudin, 2014). The instrument reliability of variables was tested via Cronbach Alphas, with all the values above recommended benchmark of 0.7 as argued by (Jöreskog, 1993). CMIN was used to measured normalized $\mathrm{x} 2$ for the model $(\mathrm{x} 2 / \mathrm{df}=2.831$, where $\mathrm{df}=130)$. The result is in line with the benchmark of $\geqslant 2.5 \leqslant 3.5$ as suggested by (Kline, 2006). The root means square error (RMSEA) shows a reliable value of 0.08 , which is within the recommended benchmark of $\geqslant 0.05 \leqslant 0.08$ as suggested by (Kenny et al., 2014). GFI (goodness of fit index) recorded 0.880 and AGFI (adjusted goodness of fit index) is 0.842 which accord to suggested value of $\geqslant 0.8$ by Marcoulides and Schumacker (2013) as marginal fit. Thus, CFI (comparative fit index) has a value of 0.932 , which is lined with $\geqslant 0.9$ recommended by (Mueller, 1997). The authors agree that CFI $\geqslant 0.9$ and RMSEA $\geqslant 0.05 \leqslant .08$ indicate strong model.

Table 4. Measurement variance analysis and reliability for organizational leadership and knowledge transfer.

\begin{tabular}{ccccc}
\hline Variable/ Indicators & Factor loadings & Cronbach Alphas & T-Value & Variance extracted \\
\hline Emotionally intelligent & & & & \\
EI1 & .74 & .853 & 2.528 & .609 \\
EI2 & .77 & & 12.632 &
\end{tabular}

Leadership traits

$\begin{array}{lr}\text { LT1 } & .78 \\ \text { LT2 } & .82 \\ \text { LT3 } & .84\end{array}$

Transformation team

TT1

TT2

TT3

13.473

Approach Toward Transfer

\section{ATT1}

ATT2

ATT3

Transfer using Social network

$\begin{array}{lr}\text { TSN1 } & .91 \\ \text { TSN2 } & .90 \\ \text { TSN3 } & .92\end{array}$

Readiness to Transfer

$\begin{array}{lc}\text { RT2 } & .76 \\ \text { RT3 } & .98 \\ \text { RT4 } & .86\end{array}$




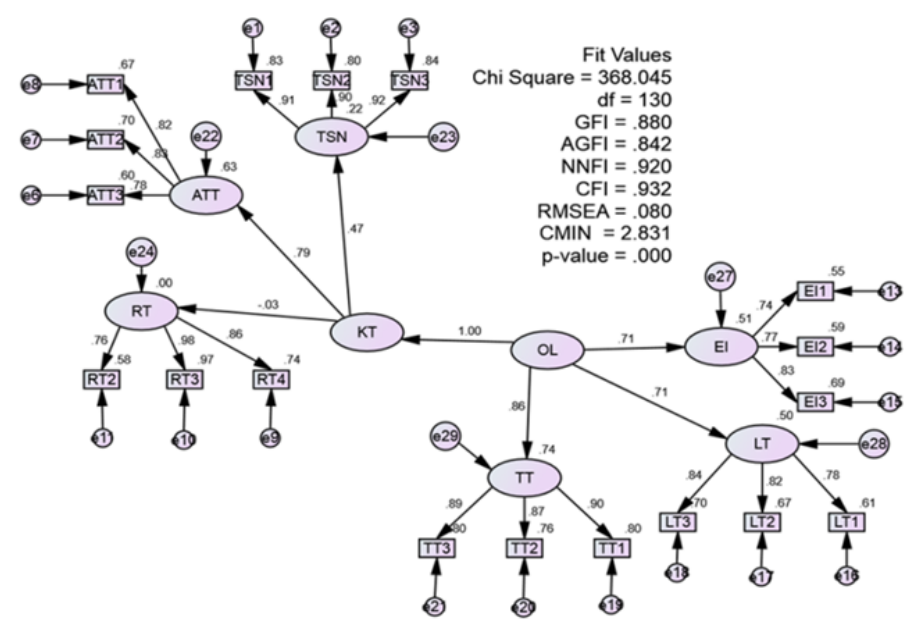

Figure 1. Confirmatory analysis of organization leadership and knowledge transfer

Note. $\mathrm{KT}=$ Knowledge Transfer, $\mathrm{RT}=$ Readiness to transfer, $\mathrm{TSN}=$ Transfer using Social network, ATT= Attitude towards transfer, $\mathrm{OL}=$ Organization Leadership, $\mathrm{TT}=$ Transformation Team, $\mathrm{LT}=$ Leadership Traits, $\mathrm{EL}=$ Emotional Intelligent.

\section{Discussion}

The effect of organizational leadership was assessed via Hypothesis 1 (H1) with the sub hypothesis range from $\mathrm{H} 1 \mathrm{a}, \mathrm{H1b}, \mathrm{H} 1 \mathrm{c}, \mathrm{H1d}, \mathrm{H} 1 \mathrm{e}$ and H1f as shown in Figure 1. The path coefficient of 0.2 and above was measured as basically substantial loading (Cohen et al., 2013). The output of confirmatory factor analysis (AMOS) demonstrated trustworthy and robust factors loading as shown in figure 2. Organizational leadership path loadings measuring $0.71,0.86$, and 0.71 for emotional intelligence, transformation team and leadership trait correspondingly, while constructing measuring knowledge transfer recorded a path loadings of $-.03,0.79$ and 0.47 in readiness to transfer, approaches towards transferring and using social means to transfer correspondingly. Organizational leadership shows the highest path loading of 1 to knowledge transfer, which implies that organizational leadership replicates personal and group potential of the construction workers to transfer their knowledge. The result analysis supported all the hypotheses of $\mathrm{H} 1$ (main hypotheses), H1a, H1b, H1c, H1d, H1e while H1f was not supported. Thus, it is suiTable to assume that organizational leadership influences the transfer of tacit knowledge in the construction organization (Figure 2 and Table 5). The significant relationship is supported by leadership emotional intelligent, leadership traits and transformation team among the organizational leadership and transferring using social networks with worker attitudes and willingness to transfer/leverage their knowledge. The prime hypothesis is supported- H1; organizational leadership can significantly influence the transfer of knowledge in construction organization.

Table 5. Structural equation model summary result

\begin{tabular}{cccc}
\hline Hypotheses & path hypotheses & path coefficient & Result \\
\hline H1a & EI can influence positively organization leadership & 0.71 & Supported \\
H1b & LT can influence positively organization leadership & 0.71 & Supported \\
H1c & TT can influence positively organization leadership & 0.86 & Supported \\
H1d & TSN can influence positively transfer of knowledge & 0.47 & Supported \\
H1e & ATT can influence positively transfer of knowledge & 0.79 & Supported \\
H1f & RT can influence positively transfer of knowledge & -.03 & Not Supported \\
H1 & Organizational leadership can positively influence the & \multirow{1}{*}{ Supported }
\end{tabular}

Note. $\mathrm{RT}=$ Readiness to transfer, $\mathrm{TSN}=$ Transfer using Social network, ATT $=$ Attitude towards transfer, $\mathrm{TT}=$ Transformation Team, LT= Leadership Traits, EL=Emotional Intelligent. 


\section{Conclusion}

It is imperious to decide that organizational leadership elicit societal solidity and societal unity among construction workers and increase their potential to transfer knowledge among their colleagues and staff member. Transferring of knowledge through a social network (codification, knowledge repositories and database) is prompted through societal solidity, cognitive process and attitude towards transfer in the construction organization. This suggests that when skilled workers in the construction organization tent to transfer their knowledge, the knowledge rotates within the technical know-how of individuals. Thus, organizational leadership has the latent to transfer and promote knowledge leverage among their associates and co-workers in construction organization. The study also reveals that transferring of knowledge is within the milieu of speculative and skill surrounded in every individual head. The finding from the research can help knowledge management canvassers as well as expertise to advance and heightened thoughtfulness of the excelling role of leadership inside the transfer of knowledge about the construction organization.

The research has a subsequent contribution to the body of knowledge in the distinct ways; first, in the production of model for a research model for empirical research that highlighted the effect of organizational leadership, and knowledge sharing on organizational performance based on the views of project managers in Nigerian construction organizations. In addition, the researcher provides a research framework for scholars and construction practitioners who intend to carry out research- related research. This research adopted three valid constructs for knowledge transfer that can be used as a reference to further studies.

\section{References}

Ajzen, I. (1991). The theory of planned behavior. Organizational behavior and human decision processes, 50(2), 179-211.

Ajzen, I. (2001). Nature and operation of attitudes. Annual review of psychology, 52(1), 27-58. http://dx.doi.org/10.1146/annurev.psych.52.1.27

Akhavan Tabassi, A., Ramli, M., Hassan Abu Bakar, A., \& Hamid Kadir Pakir, A. (2014). Transformational leadership and teamwork improvement: the case of construction firms. Journal of Management Development, 33(10), 1019-1034. http://dx.doi.org/10.1108/JMD-01-2012-0003

Albino, V., Garavelli, A., \& Gorgoglione, M. (2004). Organization and technology in knowledge transfer. Benchmarking: An International Journal, 11(6), 584-600. http://dx.doi.org/10.1108/14635770410566492

Ashforth, B. E., \& Mael, F. (1989). Social identity theory and the organization. Academy of management review, 14(1), 20-39. Retrieved from http://www.jstor.org/sTable/258189

Barnes, S. J. (2001). Knowledge management systems: theory and practice. Cengage Learning.

Bollen, K. A. (1998). Structural equation models. Wiley Online Library.

Byrne, B. M. (2012). Structural equation modeling with Mplus: Basic concepts, applications, and programming. Routledge.

Byrne, B. M. (2013). Structural equation modeling with AMOS: Basic concepts, applications, and programming. Routledge.

Cohen, J. (2013). Statistical power analysis for the behavioral sciences. Routledge Academic.

Cohen, J. F., \& Olsen, K. (2015). Knowledge management capabilities and firm performance: A test of universalistic, contingency and complementarity perspectives. Expert Systems with Applications, 42(3), 1178-1188. http://dx.doi.org/10.1016/j.eswa.2014.09.002

Cohen, J., Cohen, P., West, S. G., \& Aiken, L. S. (2013). Applied multiple regression/correlation analysis for the behavioral sciences. Routledge.

Davenport, T. H., De Long, D. W., \& Beers, M. C. (1997). Building successful knowledge management projects. Center for business innovation working paper, 4 .

Gallos, J. V. (2014). Business leadership: a Jossey-Bass reader. John Wiley \& Sons.

Goleman, D., Boyatzis, R., \& McKee, A. (2013). Primal Leadership, With a New Preface by the Authors: Unleashing the Power of Emotional Intelligence. Harvard Business Press.

Grint, K. (2007). Learning to lead: can Aristotle help us find the road to wisdom? Leadership, 3(2), 231. http://dx.doi.org/10.1177/1742715007076215

Hoch, J. E., \& Kozlowski, S. W. (2014). Leading virtual teams: Hierarchical leadership, structural supports, and 
shared team leadership. Journal of applied psychology, 99(3), 390. http://dx.doi.org/10.1177/0149206 314559946

Jöreskog, K. G. (1993). Testing structural equation models. Sage focus editions, 154, 294.

Kenny, D. A., Kaniskan, B., \& McCoach, D. B. (2014). The performance of RMSEA in models with small degrees of freedom. Sociological Methods \& Research. http://dx.doi.org/10.1177/0049124114543236

Kline, R. B. (2006). Structural equation modeling. New York: The Guilford Press.

Koballa, T. R. (1988). Attitude and related concepts in science education. Science Education, 72(2), 115-126. http://dx.doi.org/10.1002/sce.3730720202

Kuo, F.-Y., \& Young, M.-L. (2008). Predicting knowledge sharing practices through intention: A test of competing models. Computers in Human Behavior, 24(6), 2697-2722. http://dx.doi.org/10.1016/j.chb. 2008.03.015

Leana, C. R., \& Pil, F. K. (2006). Social capital and organizational performance: Evidence from urban public schools. Organization Science, 17(3), 353-366. Retrieved from http://www.jstor.org/sTable/25146039

Lopez, R. (2014). The Relationship between Leadership and Management: Instructional Approaches and its Connections to Organizational Growth. Journal of Business Studies Quarterly, 6(1).

Marcoulides, G. A., \& Schumacker, R. E. (2013). Advanced structural equation modeling: Issues and techniques. Psychology Press.

Mueller, R. O. (1997). Structural equation modeling: Back to basics. Structural Equation Modeling: A Multidisciplinary Journal, 4(4), 353-369.

Müller, R., \& Turner, R. (2007). The influence of project managers on project success criteria and project success by type of project. European Management Journal, 25(4), 298-309. http://dx.doi.org/10.1016/j.emj. 2007.06.003

Nonaka, I. (2005). Knowledge management: critical perspectives on business and management (Vol. 2). Taylor $\&$ Francis.

Nonaka, I., Toyama, R., \& Konno, N. (2005). SECI, ba and leadership: a unified model of dynamic knowledge creation. Knowledge Management: Critical Perspectives on Business and Management, 2, 317.

Nousala, S., Hall, W., \& John, S. (2007). Transferring tacit knowledge in extended enterprises. Proceedings of the 2007 International Conference on Information and Knowledge Engineering.

O'Dell, C., \& Grayson, C. J. Jr. (1998). The transfer of internal knowledge and best practice: if only we knew what we know. New York: The Free Press.

Parent, R., Roy, M., \& St-Jacques, D. (2007). A systems-based dynamic knowledge transfer capacity model. Journal of Knowledge Management, 11(6), 81-93. http://dx.doi.org/10.1108/13673270710832181

Pemsel, S., \& Müller, R. (2012). The governance of knowledge in project-based organizations. International Journal of Project Management, 30(8), 865-876. http://dx.doi.org/10.1016/j.ijproman.2012.02.002

Pollack, J. (2012). Transferring knowledge about knowledge management: Implementation of a complex organisational change programme. International Journal of Project Management, 30(8), 877-886 http://dx.doi.org/10.1016/j.ijproman.2012.04.001.

Rowley, J. E. (2008). Organizing knowledge: an introduction to managing access to information. Ashgate Publishing, Ltd.

Senaratne, S., Samaraweera, A., Kumaraswamy, M., \& Ruwanpura, J. (2015). Construction project leadership across the team development process. Built Environment Project and Asset Management, 5(1). http://dx.doi.org/10.1108/BEPAM-10-2012-0049

Singh, S., Chan, Y. E., \& McKeen, J. D. (2006). Knowledge Management Capability and Organizational Performance: A Theoretical Foundation. Proceedings of the 2006 Conference at the University of Warwick, Coventry, 1-54.

Szulanski, G. (2000). The process of knowledge transfer: A diachronic analysis of stickiness. Organizational behavior and human decision processes, 82(1), 9-27. http://dx.doi.org/10.1006/obhd.2000.2884

Toor, S.-u.-R., \& Ofori, G. (2008). Leadership for future construction industry: Agenda for authentic leadership. International Journal of Project Management, 26(6), 620-630. 
Turner, J. R., \& Müller, R. (2006). Choosing appropriate project managers: Matching their leadership style to the type of project. Proceedings of the 2006. Project Management Institute. http://dx.doi.org/10.1016/j.emj. 2007.06.003

Turner, K. L., \& Makhija, M. V. (2006). The role of organizational controls in managing knowledge. Academy of Management Review, 31(1), 197-217. http://www.jstor.org/sTable/20159192

Von Krogh, G., Nonaka, I., \& Rechsteiner, L. (2012). Leadership in organizational knowledge creation: a review and framework. Journal of Management Studies, 49(1), 240-277. http://dx.doi.org/10.1111/j.1467-6486. 2010.00978.x

Voon, W. (2007). Knowledge management repositories: Supporting knowledge work and activity in organizations. Rutgers The State University of New Jersey - New Brunswick, Ann Arbor.

Widén-Wulff, G., \& Ginman, M. (2004). Explaining knowledge sharing in organizations through the dimensions of social capital. Journal of Information Science, 30(5), 448-458. http://dx.doi.org/10.1177/01655515040 46997

Xu, Q., \& Ma, Q. (2008). Determinants of ERP implementation knowledge transfer. Information \& Management, 45(8), 528-539. http://dx.doi.org/10.1016/j.im.2008.08.004

Yang, L.-R., Huang, C.-F., \& Hsu, T.-J. (2013). Knowledge leadership to improve project and organizational performance. International Journal of Project Management. http://dx.doi.org/10.1016/j.ijproman.2013.01. 011(0)

Yang, S.-C., \& Farn, C.-K. (2009). Social capital, behavioural control, and tacit knowledge sharing-A multi-informant design. International Journal of Information Management, 29(3), 210-218. http://dx.doi.org/10.1016/j.ijinfomgt.2008.09.002

Zainudin, A. (2014). A Handbook on SEM for Academicians and Practitioners. MPWS Training Center, Bander Baru Bangi, Selangor: MPWS Rich Resources.

\section{Copyrights}

Copyright for this article is retained by the author(s), with first publication rights granted to the journal.

This is an open-access article distributed under the terms and conditions of the Creative Commons Attribution license (http://creativecommons.org/licenses/by/3.0/). 